\title{
WILLIAMSONIA CAROLINENSIS SP. NOV. AND ASSOCIATED EOGINKGOITES FOLIAGE FROM THE UPPER TRIASSIC PEKIN FORMATION, NORTH CAROLINA: IMPLICATIONS FOR EARLY EVOLUTION IN THE WILLIAMSONIACEAE (BENNETTITALES)
}

\author{
Christian Pott ${ }^{1, *}$ and Brian J. Axsmitht \\ *Department of Biology, University of South Alabama, Mobile, Alabama 36688, USA; and +Department of Palaeobiology, \\ Swedish Museum of Natural History, Box 50007, Stockholm SE-104 05, Sweden
}

Editor: Patrick S. Herendeen

\begin{abstract}
Premise of research. Few reproductive organs unequivocally attributable to the important but enigmatic Mesozoic seed plant order Bennettitales have been described from the Triassic of all of North America outside of Greenland. Here, the first ovulate reproductive organs (gynoecia) of the group from the Upper Triassic of eastern North America are described and assigned to a proposed new species, Williamsonia carolinensis, of the family Williamsoniaceae.
\end{abstract}

Methodology. The excellently preserved plant fossils were investigated using cuticular analysis and light, fluorescence, and scanning electron microscopy.

Pivotal results. The description is based on 10 specimens from the Late Triassic (Carnian) Pekin Formation of North Carolina. They are interpreted as representing progressive developmental stages. Williamsonia carolinensis lacks a corona (sterile apical projection of the receptacle) and bracts subtending the receptacle. The lack of bracts is particularly unusual and appears to be the original condition and not a preservation artifact based on their absence even on immature specimens. The two largest specimens, interpreted as mature gynoecia, occur together on the same slab in exclusive association with the unusual bennettitalean leaf Eoginkgoites, suggesting that these organs were produced by the same parent plant species.

Conclusions. The unique features of W. carolinensis, along with the probable affinity with Eoginkgoites foliage, expands the known diversity of the Williamsoniaceae and supports previous suggestions of remarkably high levels of morphological disparity in the earliest history of the Bennettitales.

Keywords: Carnian, bennettitalean reproductive structures, bennettitalean foliage, Newark Supergroup, Deep River Basin.

\section{Introduction}

Williamsoniaceae of the Bennettitales is an extinct family of enigmatic plants whose phylogenetic relationships are not completely understood (Pott 2014a). The group is considered the older of the two families of the Bennettitales, but the Williamsoniaceae is potentially paraphyletic, encompassing all forms not fitting within the family Cycadeoidaceae. The earliest records come from Carnian deposits from several parts of the world with local abundances in central Europe, Svalbard, and South Africa (Pott 2014b). Reproductive structures are traditionally assigned to Williamsonia Carruthers (ovulate cones), Weltrichia Braun (microsporangiate organs), or Bennetticarpus Harris (matured seed cones), which is a pragmatic

\footnotetext{
${ }^{1}$ Author for correspondence; e-mail: christian.pott@nrm.se.
}

Manuscript received September 2014; revised manuscript received October 2014; electronically published January 2, 2015. division deployed by Harris (1969) probably not indicative of natural relationships (Pott et al. 2010a; Pott 2014a). Williamsonia ovulate cones consist of a central solid receptacle, which is usually ovoid to pear shaped, and a region of densely packed, alternating ovules, each of which is typically surrounded by 6-8 interseminal scales (Harris 1969; Pott 2014a). Ovule apices and interseminal scale heads form a characteristic pattern on the surface of the ovulate cones. The micropyles of the ovules project beyond the surface during anthesis but might have retracted during seed maturation by swelling of the apical portions of the interseminal scales (Harris 1969; Pott et al. 2010a; Pott 2014a).

Several additional genera constitute early representatives of the Williamsoniaceae or Bennettitales such as Haitingeria Krasser, Pramelreuthia Krasser, Bennettistemon Harris, Vardekloeftia Harris, Leguminanthus Kräusel and Schaarschmidt, and Lunzia Krasser (Krasser 1917, 1919; Harris 1932; Kräusel and Schaarschmidt 1966; Ash and Litwin 1996; Weber 2008; Pott et al. 2010a), the affinities of which are not unequivocally 
resolved. The Rhaetian Wielandiella Nathorst emend. Pott, defined by Nathorst (1909) to comprise bisporangiate cones, was recently emended as the first genus encompassing whole plants with separate ovulate and microsporangiate organs; however, the microsporangiate structure and the mature seed cone have yet to be confirmed by organic connection (Pott 2014a). Even the type of Williamsonia (viz., Williamsonia gigas [Lindley and Hutton] Carruthers) was originally described as a whole plant (Carruthers 1870). The Jurassic Williamsoniella Thomas is the only williamsoniaceous reproductive structure confidently confirmed as bisporangiate (Harris 1969; Crane and Herendeen 2009; Zavialova et al. 2009; Pott and McLoughlin 2014): a central ovulate organ similar in structure to Williamsonia is surrounded by a whorl of complex microsporangiate organs-a structure similar to the elaborate forms of Cycadeoidaceae (Wieland 1906, 1916; Watson and Sincock 1992). The reproductive structures of the latter, however, seem to have never fully opened and were probably self-pollinated (Delevoryas 1968).

Whereas the Lower Cretaceous of North America is well known for its local abundance of cycadeoid fossils (Cycadeoidea Buckland ex Lindley and Hutton; e.g., Wieland 1906, 1916; Delevoryas 1968), the record of reproductive structures of bennettitaleans from the Triassic (outside of Greenland) is scarce. Foliage, in contrast, occurs locally in abundance but is usually of low diversity (e.g., Eoginkgoites Bock or Laurozamites Weber and Zamudio-Varela; Ash 1976; Axsmith et al. 1995; Weber and Zamudio-Varela 1995; Weber 2008). Here, we report on the first unequivocal record of bennettitalean ovulate structures from the Newark Supergroup-and one of only three from the Triassic of the entire continent-and consider its possible implications for the developmental biology and early history of the group. Intriguing association evidence for affinity with Eoginkgoites sterile foliage, which would increase the known diversity of leaf types in the Williamsoniaceae, is also presented.

\section{Material, Methods, and Geological Setting}

\section{Material and Methods}

In total, eight specimens yielding 10 compressions and impressions of ovulate williamsoniaceous reproductive structures have been examined. The specimens were collected in the 1960s by Robert C. Hope and associates while the quarry was active, but they were never described or figured. They are now stored in the University of Kansas (KU) paleobotanical collections in Lawrence, Kansas, under accession numbers T2151, T2152, T2155b, T2156, T2158, T2160, T2417, and T3578 (slab with three cones). The specimens were photographed with a Pentax K20 digital camera on a copy stand and a Nikon DSri-1 digital camera through a Nikon SMZ1500 dissecting microscope; oblique lightning was used to enhance contrast.

Most of the fossils are preserved as impressions with some limited regions of organic material that is extremely resistant to treatment for cuticles. About 20 years ago, B. J. Axsmith extracted a small amount of organic material from specimen T2151 and treated it in Schulze's reagent with limited success. Recently, cuticular analysis was attempted for another specimen (i.e., T2417) by C. Pott. It was first examined under an
Olympus BX51 light microscope, which was modified for epifluorescence microscopy. Subsequently, a sample of the organic remains was treated according to standard maceration procedures (e.g., Pott and Kerp 2008; Pott and McLoughlin 2009) to obtain cuticle fragments for light microscopy. To remove sediment remains, the organic material was treated with $40 \%$ hydrofluoric acid for $1-5 \mathrm{~d}$ and then bathed in Schulze's reagent $\left(30 \% \mathrm{HNO}_{3}\right.$ with a few crystals of $\left.\mathrm{KClO}_{4}\right)$ for up to $2 \mathrm{wk}$ for maceration. The coal layer was then removed by applying $5 \%-10 \%$ potassium hydroxide $(\mathrm{KOH})$ immediately followed by neutralization in water. However, all attempts to visualize cuticles from this specimen failed, and after maceration it was revealed that the organic remains consisted of pure coal. It was impossible to analyze the surface using scanning electron microscopy (SEM) because the coaly samples pulverized completely while being separated from the rock.

\section{Geological Setting}

All of the described specimens are from the classic Boren Clay Products pit locality near Gulf, North Carolina, which exposes sediments of the middle Pekin Formation. The Pekin Formation is the lowest formation of the Deep River Basin, which is the southernmost-exposed basin of the Newark Supergroup and extends from central North Carolina into northern South Carolina. The Boren pit occurs near the western margin of the Sanford Subbasin (fig. 1). Based on correlation with paleomagnetically dated cores, the plant-bearing layers were deposited just south of the paleoequator during the Carnian Stage of the Late Triassic Period about 226-228 million years ago (Whiteside et al. 2011).

The flora of the Boren pit is one of the oldest, most thoroughly documented, and relatively recently studied Triassic floras of the Newark Supergroup; however, many aspects of this assemblage remain undocumented (Gensel 1986; Axsmith et al. 2001). Although some fossil plants can still be obtained from the now defunct Boren pit, the best material was collected during the 1960s and early 1970s when rapid salvage collections were made just ahead of the open-pit mining operations happening at that time (Hope and Patterson 1969; R. C. Hope, personal communication). The most productive unit was an approximately $280-\mathrm{cm}$ section of gray and dusky yellow siltstones exposed in the southwestern end of the quarry that has been interpreted as having been deposited on an alluvial plain by meandering streams under warm, moist conditions with seasonal rainfall (Gensel 1986).

Observations made during the main collecting phase by Hope and Patterson (1969) indicate that the plant fossils were well distributed through the most productive unit and were very well preserved in terms of articulation. Although the collectors noted the presence of minor cross bedding and macerated plant fragments indicating transport of some of the material, they concluded that "almost all the evidence indicates a relatively undisturbed environment" (Hope and Patterson 1969, p. 4). This conclusion received additional support with the subsequent documentation of fossils such as cycad and bennettitalean stems with attached leaves, fern leaves still attached to rhizomes, and the preservation of very fragile plants such as the filmy fern Hopetedia Axsmith, Krings and Taylor (Gensel 1986; Axsmith et al. 2001). 


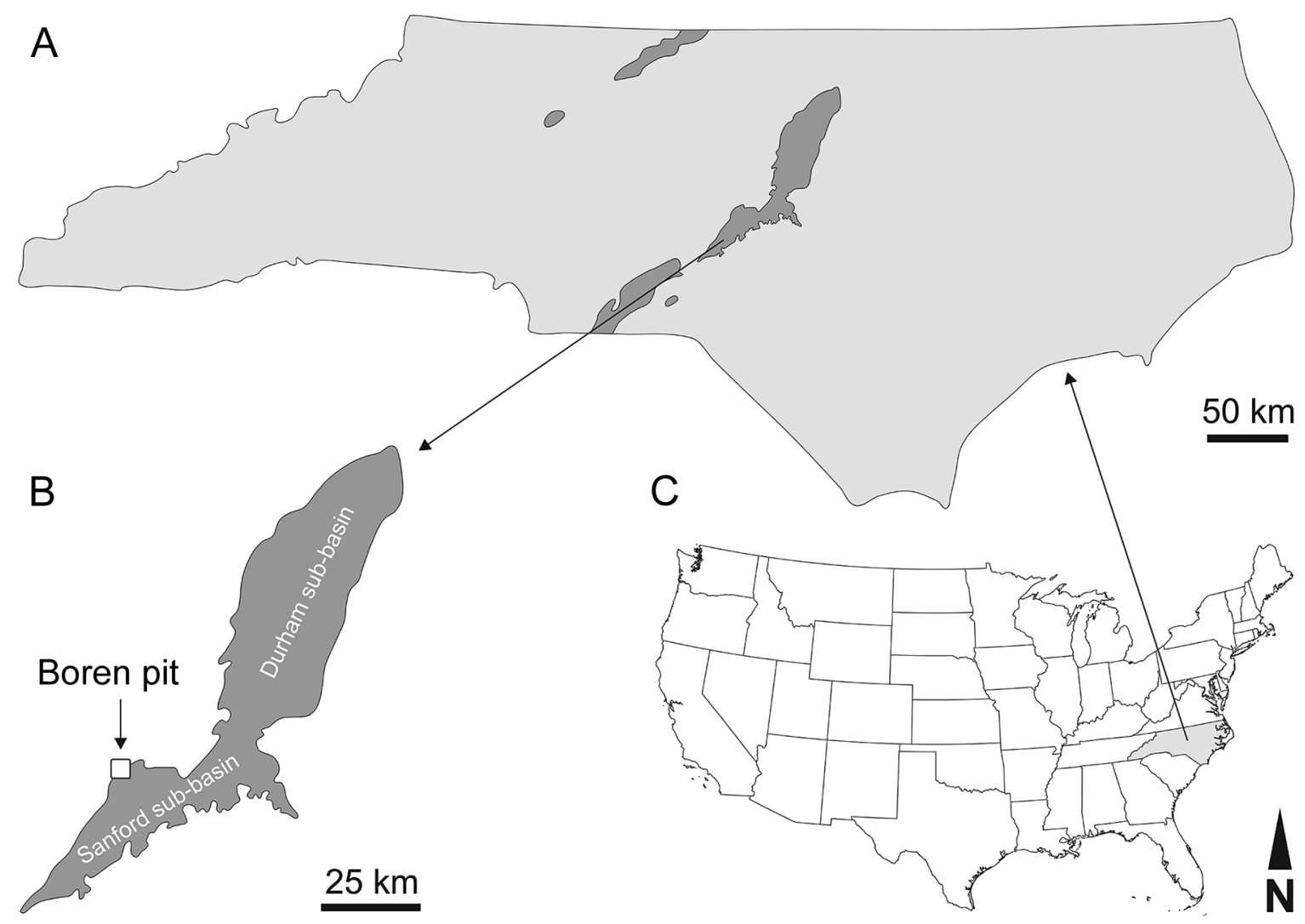

Fig. 1 Maps indicating the position of the fossil locality. A, North Carolina with the Deep River Basin, which is the southernmost-exposed basin of the Newark Supergroup extending from central North Carolina into northern South Carolina. B, Deep River Basin indicating the position of the Boren Clay Products pit locality near Gulf, North Carolina, where the fossils were obtained. C, Map of the United States with the position of North Carolina indicated. Based on a map provided by Andrew Heckert of Appalachian State University, Boone, North Carolina.

\section{Results}

Examination of the specimens revealed that they represent a species new to science, assignable to the bennettitalean family Williamsoniaceae. Its formal description follows.

\section{Systematic Paleontology}

Order-Bennettitales Engler 1892

Family-Williamsoniaceae Carruthers 1870

Genus-Williamsonia Carruthers 1870

Type. Williamsonia gigas (Lindley and Hutton) Carruthers 1870, from the Bajocian, Middle Jurassic, of Yorkshire, United Kingdom.

\section{Species-Williamsonia carolinensis C.Pott and Axsmith sp. nov.}

Etymology. The specific epithet refers to the US state of North Carolina, where the material was discovered.

Specific diagnosis. Bennettitalean ovuliferous structure. Developing gynoecia spherical in outline, mature gynoecia ovoid in outline, circular in diameter, apically bluntly pointed. Cen- tral receptacle with densely packed ovules and interseminal scales covering the entire structure except for the basal attachment point. Surface of mature gynoecia covered with numerous laterally fused hexagonal shields, 6-7 surrounding a micropylar tube, interseminal scales slender, long stalked, widened at the apical end, alternating with elongate oval ovaries with long micropylar tubes. Corona absent. Bracts not preserved.

Holotype. T2155b; stored in the University of Kansas (KU) paleobotanical collections in Lawrence, Kansas; here figured in figure $2 B-2 E$.

Epitypes. T2151 (fig. 3A, 3B), T2417 (fig. 5); both specimens help to interpret the different proposed developmental stages and yielded the surface structures used in the specific description.

Additional material. T2152, T2156, T2158, T2160, T3578.

Type locality. Clay pit of the Boren Clay Products Company, $2.5 \mathrm{~km}$ northwest of Gulf, Chatham County, North Carolina (Hope and Patterson 1969).

Type horizon and age. Middle Pekin Formation, Newark Supergroup; Late Triassic (Carnian; Whiteside et al. 2011).

Distribution. So far as known, restricted to the type locality and stratum

Description. Eight samples yielding 10 ovuliferous reproductive structures (hereafter termed "gynoecia") are preserved 

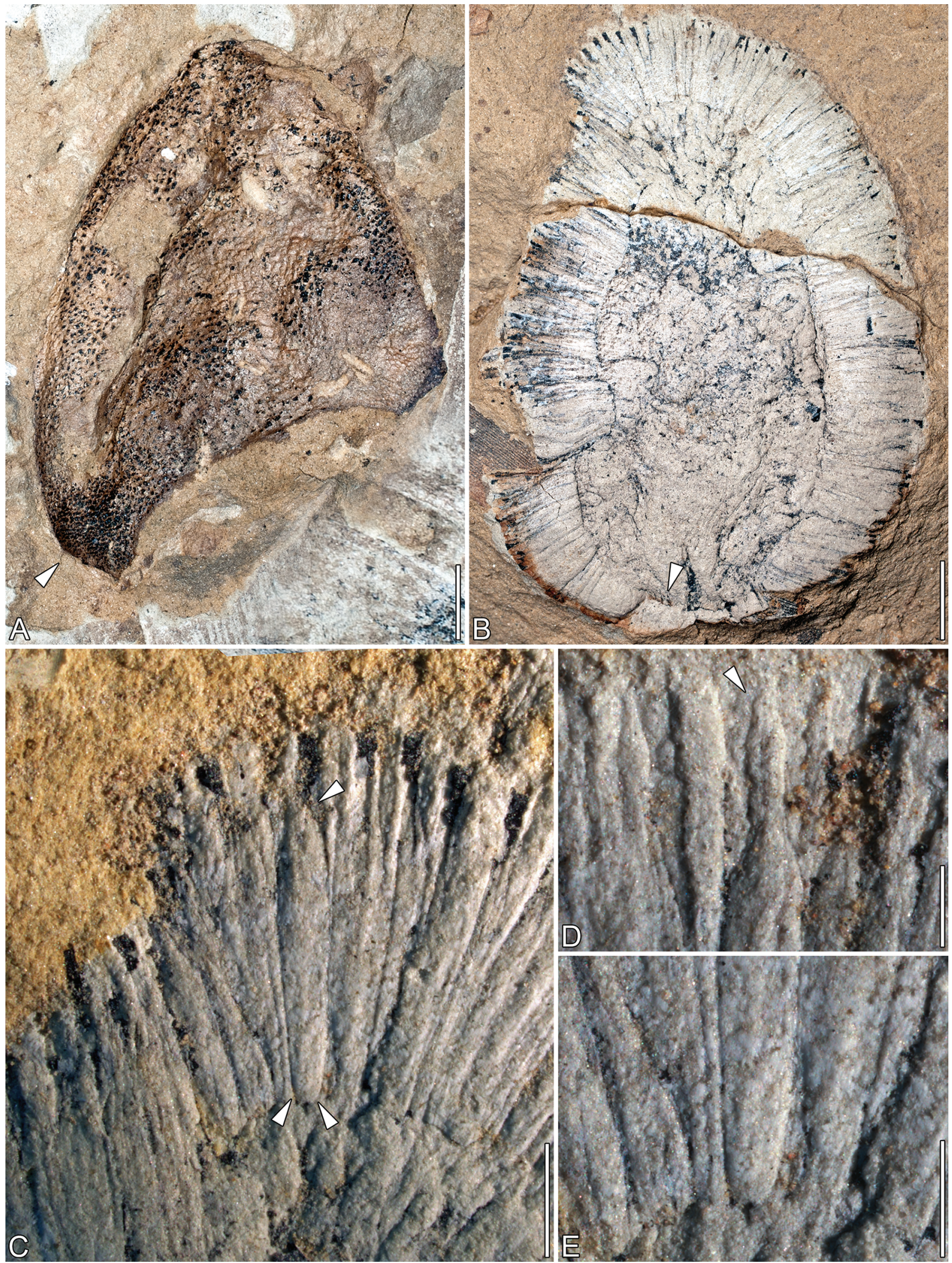

Fig. 2 Matured gynoecia of Williamsonia carolinensis from the Clay pit of the Boren Clay Products Company, Chatham County, North Carolina. A, Surface view; note the smaller size and denser packing of the basalmost interseminal scales and ovules (arrowhead). Specimen T3578. B, Cross section through a matured gynoecium; note the attachment area of the supporting axis (arrowhead). Specimen T2155. $C$, Enlargement of the apical portion of the gynoecium in $B$, elucidating the interseminal scales and ovules with micropyles (arrowheads). Specimen T2155. D, Enlargement of the apical portion of $C$ showing adjacent ovules with well-developed micropyles (arrowhead). Specimen T2155. E, Enlargement of the basal portion of the ovules shown in C. Specimen T2155. Scale bars: $10 \mathrm{~mm}(A, B), 5 \mathrm{~mm}(C), 1 \mathrm{~mm}(D, E)$. 

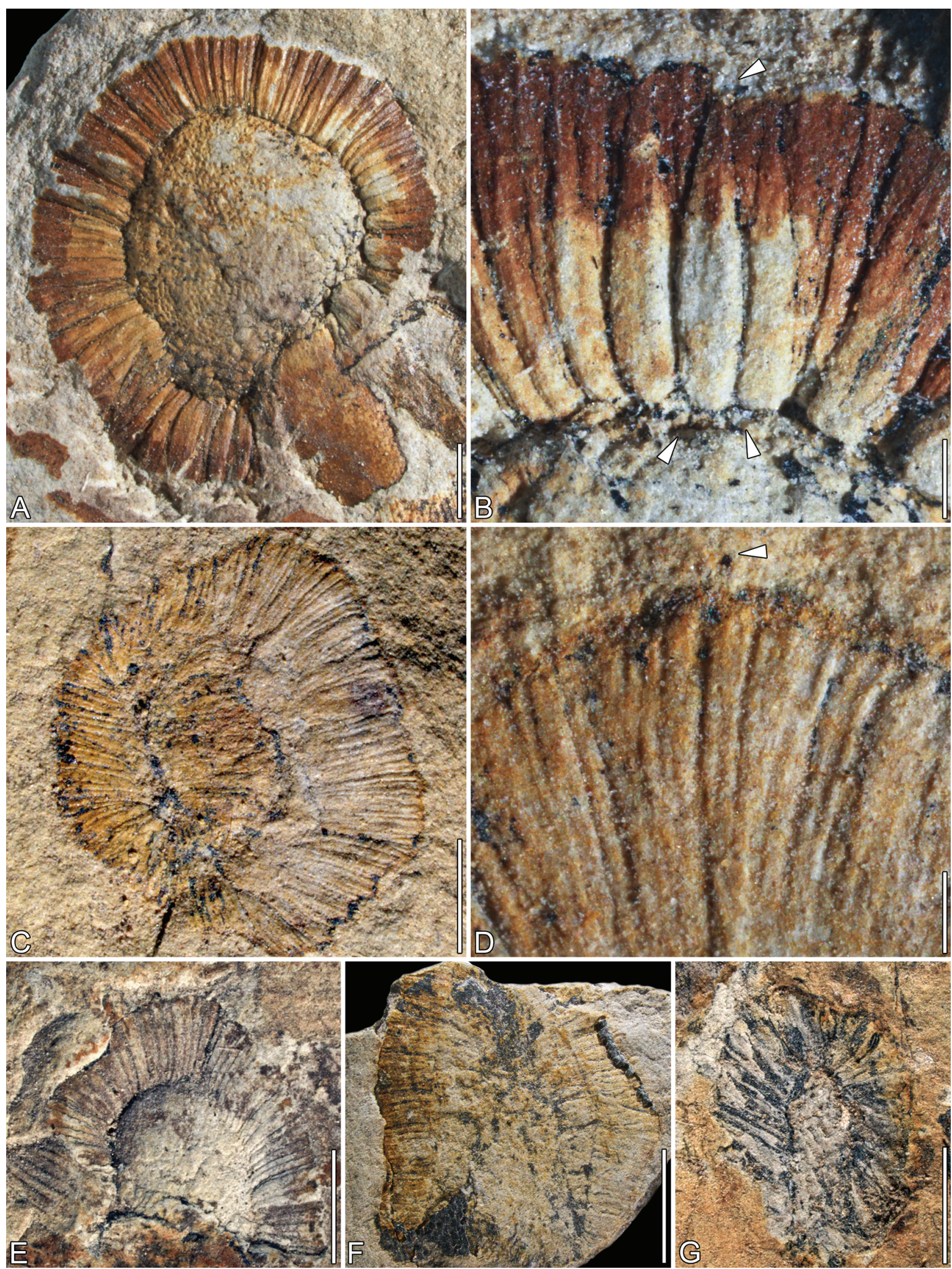

Fig. 3 Immature gynoecia of Williamsonia carolinensis from the Clay pit of the Boren Clay Products Company, Chatham County, North Carolina. A, Complete gynoecium in cross section; note the scales are all of the same type. Specimen T2151. B, Enlargement of the layer of interseminal scales and ovules of the specimen shown in $A$; note the scales are all of the same type, with initiating differentiation visible (arrowheads). Specimen T2151. C, Another complete gynoecium in cross section; note the scales are all of the same type. Specimen T2152. $D$, Enlargement of the layer of interseminal scales and ovules of the specimen shown in $C$; note the scales are all of the same type; the arrowhead points to a possible projecting micropyle. Specimen T2152. E-G, Three different gynoecia in cross section. Specimens T2160 $(E)$, T2158 $(F)$, T2156 (G). Scale bars: $10 \mathrm{~mm}(A, C, E-G), 1 \mathrm{~mm}(B, D)$. 
as impressions, some of which yield remains of organic material (compressions). All gynoecia show a similar structure, with a solid receptacle covered entirely with a thick layer (usually half as thick as the receptacle) of densely packed, thin scales (figs. 2B, 3A, 3C, 3E-3G). The latter is visible on most specimens in cross section because the scales on the surface visible to the viewer most likely were removed when the matrix was split. In a few specimens, the entire surface is preserved (figs. $2 A$, $4 B, 4 C)$ and densely covered with scales, of which only the heads are visible. The density of scales decreases from the base of the gynoecium toward its apex (e.g., fig. $2 A, 2 B$ ), whereas their diameter increases. The attachment point is ca. $7-8 \mathrm{~mm}$ wide; no petiole or supporting axis is preserved (fig. $2 B$ ). The ovoid shape of the gynoecia and the presence of an attachment point in cross section (e.g., fig. $2 B$ ) clearly indicate that the gynoecia have been sectioned longitudinally. A corona, if present, would be expected to be visible at least in specimen T2155 (fig. 2B), which is a perfect cross section of a gynoecium of W. carolinensis.

Two types of gynoecia can be discerned. The first (interpreted as developing gynoecia) is spherical in outline and up to $11.6 \mathrm{~mm}$ in diameter (fig. 3); the spherical receptacle is covered with densely packed, undefined, 2.3-3.1-mm-long and 200-350- $\mu \mathrm{m}$-wide scales; interseminal scales and incipient ovules cannot be distinguished (fig. $3 A-3 D$ ). The second type (interpreted as matured gynoecia) is represented by much larger, 34.7-44.2-mm-long and 20.1-29.6-mm-wide, cones ovoid in outline with a bluntly pointed apex (fig. 2). The elongate receptacles are similarly covered by densely packed, 6.0-6.3-mm-long, scales. But here, the interseminal scales (130-200 $\mu \mathrm{m}$ wide) and ovules ( $~ 850 \mu \mathrm{m}$ wide) can easily be discriminated (fig. $2 \mathrm{C}-2 \mathrm{E}$ ). Ovules are oblong-oval in outline with an elongate micropylar tube (1.1-1.3 mm long; fig. 2C, $2 D)$ that does not project beyond the gynoecium surface; interseminal scales have a long, slender stalk that widens apically (fig. 2E).

One specimen (T2417) is interpreted as representing an intermediate developmental stage, as the gynoecium is $23.0 \mathrm{~mm} \times$ $15.9 \mathrm{~mm}$ in outline and appears with its almost triangular shape transitional between the proposed spherical early developmental stage and the ovoid mature form (fig. $5 \mathrm{~A}$ ). Developing micropyles projecting beyond the surface of the gynoecium indicate the receptive (anthetic) stage of the gynoecium in this specimen (fig. 5B).

Bracts have not been found attached to the gynoecia, nor have isolated bracts been found in the KU collections or in the field by B. J. Axsmith. Gensel (1986) lists sterile bracts of Williamsonia, but these are not described or illustrated. One specimen is indicative of attached slender, parallel-sided bracts (fig. 4C), but they lack the typical lanceolate appearance and outline of cycadophyte bracts (Harris 1969; Pott 2014a). It can also not entirely be excluded that these remains represent portions of leaflets of the Eoginkgoites sterile foliage occurring scattered all over the specimens (fig. 4).

The few pieces of cuticle obtained show portions of the head of an interseminal scale with the densely spaced, thickwalled, small, central cells surrounded by larger, thinnerwalled cells including radially oriented stomata (fig. 6). The latter, however, are very poorly preserved, but the whole preserved portion is generally similar to the interseminal-scale head cuticles published by Hsü (1948), Pott et al. (2010a), and Pott $(2014 a)$.

Some of the gynoecia are found isolated, but the two largest mature specimens occur close together on the same slab among a layer of detached leaves of Eoginkoites sidneyi Axsmith, Taylor, Delevoryas and Hope (fig. 4). Cuticles of Eoginkgoites demonstrate the bennettitalean affinity of this leaf type (Ash 1976; Axsmith et al. 1995). Although not supported by attachment evidence, this association may indicate that E. sidneyi and W. carolinensis were produced by the same parent plant species.

Remark on E. sidneyi. Eoginkgoites sydneyi was introduced by Axsmith et al. (1995) honoring the contributions of Sidney Ash, Albuquerque, to our understanding of the Late Triassic floras of North America. Unfortunately, the name was mistyped as "Sydney Ash" in the article during revision and, despite annotation, was not corrected in the final proofing of the article. This led to misspelling of the species epithet as "sydneyi." To correct this typographical error according to article 60 of the International Code of Nomenclature for Algae, Fungi, and Plants (Melbourne Code) (McNeill et al. 2012), we here propose the correct name of this species as Eoginkgoites sidneyi Axsmith, Taylor, Delevoryas and Hope.

\section{Discussion}

\section{Classification and Interpretation of Williamsonia carolinensis}

Classification. Gynoecia of W. carolinensis have so far only been found detached from the parent plants, and none of them show evidence of the bracts that typically surround ovulate and microsporangiate reproductive structures in the Williamsoniaceae (e.g., Harris 1969; Pott et al. 2010a; Pott 2014a). Diagnostic cuticular characters such as brachyparacytic (= syndetocheilic) stomata could not be observed with entire certainty due to poor preservation of cuticles. However, the general outer morphology and internal organization of the gynoecia are typical for williamsoniaceous ovulate cones (see, e.g., Harris 1969; Pott 2014a). In the absence of any other appropriate genus, the species under study is here assigned to Williamsonia following the short and rather technical diagnosis given by Harris (1969), which does not include the presence of a corona or bracts. Following the summary of characteristics of Williamsonia, Wielandiella, and Williamsoniella outlined by Pott (2014a, table 2), the majority of Williamsonia ovulate structures are characterized by a corona and several whorls of sterile bracts. Consequently, the present species could perhaps be accommodated in Wielandiella based on the absence of a corona, smooth micropyles projecting above the gynoecium surface, and reduced whorls or complete absence of bracts. However, Wielandiella ovulate structures have consistently been found attached to short shoots or associated with divaricate branching axes yielding Anomozamites foliage (Harris 1932; Pott 2014a; Pott and McLoughlin 2014). Axes of W. carolinensis are unknown, and the gynoecia are, in contrast, associated with different foliage, viz., Eoginkgoites, which is an unusual bennettitalean leaf form endemic to the Late Triassic of the Newark Supergroup and the Chinle formations (Ash 1976; Axsmith et al. 

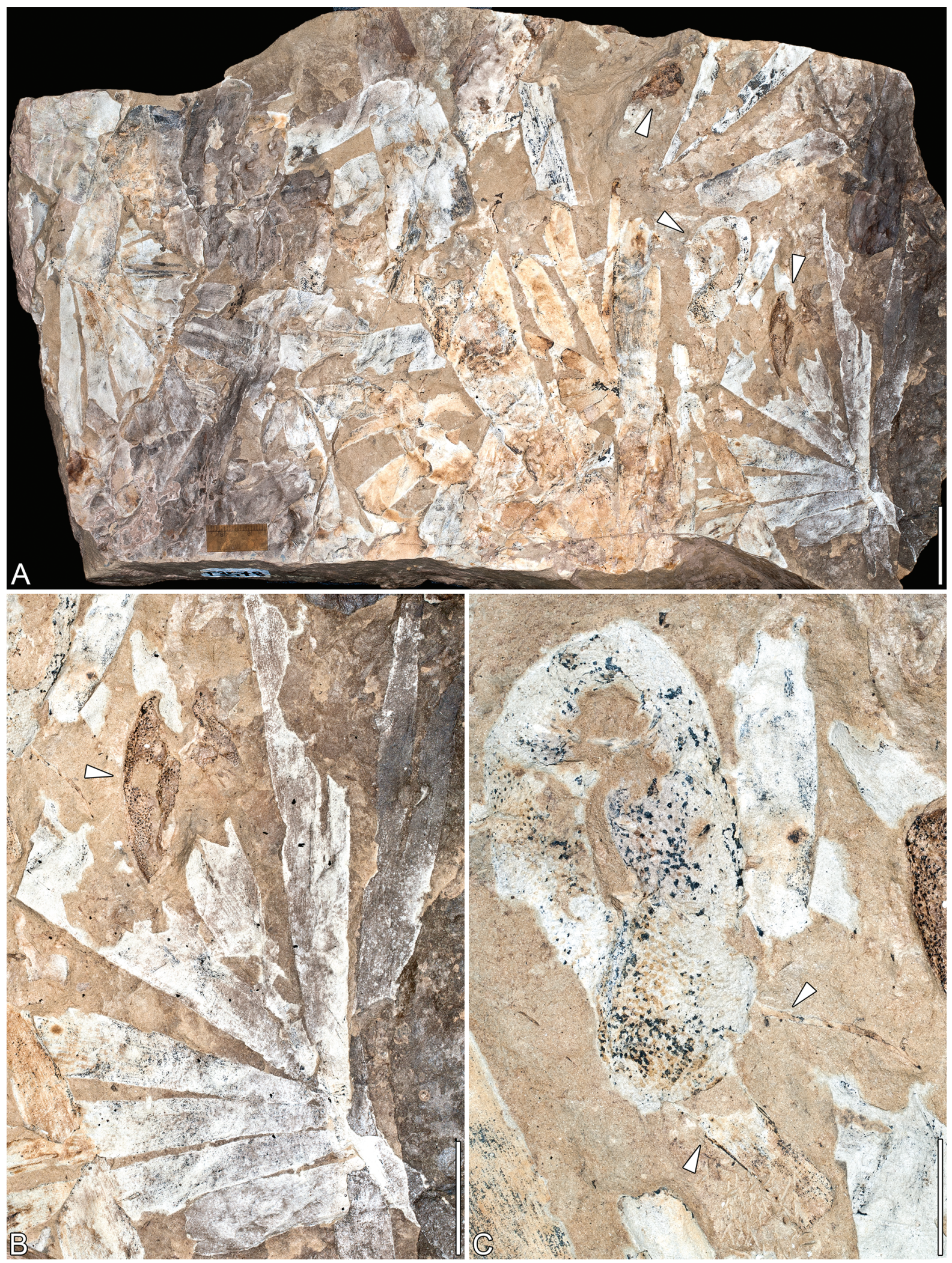

Fig. 4 Williamsonia carolinensis and Eoginkgoites sidneyi from the Clay pit of the Boren Clay Products Company, Chatham County, North Carolina. A, Slab with several W. carolinensis specimens (arrowheads) nested among abundant, overlapping sterile foliage specimens of E. sidneyi. Specimen T3578. B, Enlargement of the lower right corner of the specimen in A, showing the outer surface of a gynoecium (arrowhead) close to a well-preserved leaf of E. sidneyi. Specimen T3578. C, Enlargement of the upper right corner of the specimen in A, showing the outer surface of another gynoecium and structures indicative of potential bracts (arrowheads); the tip of one additional gynoecium is visible at the right image margin. Specimen T3578. Scale bars: $30 \mathrm{~mm}(A), 20 \mathrm{~mm}(B), 10 \mathrm{~mm}(C)$. 

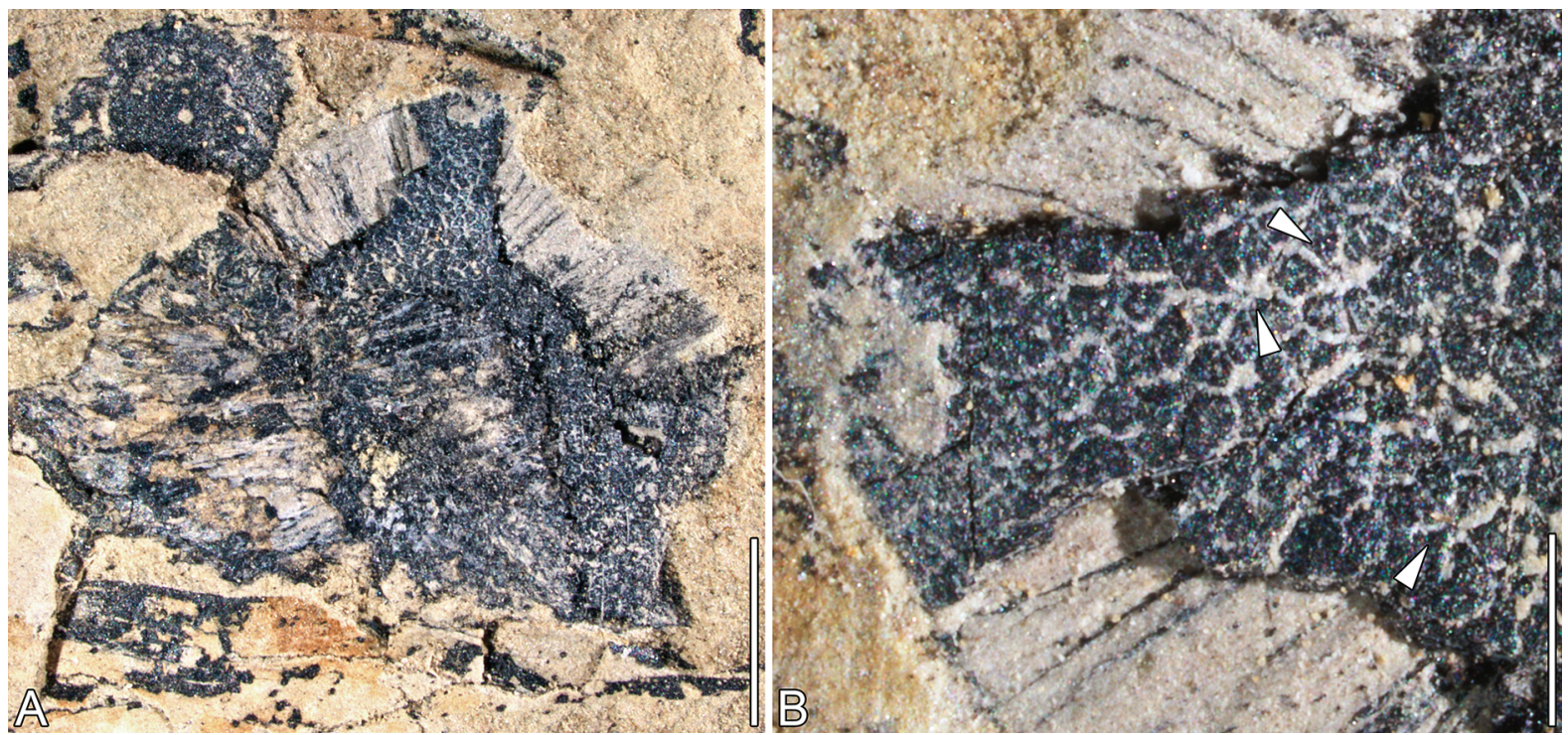

Fig. 5 Developing gynoecium of Williamsonia carolinensis from the Clay pit of the Boren Clay Products Company, Chatham County, North Carolina. A, Complete gynoecium in cross section and surface view. Specimen T2417. B, Enlargement of a portion of the organically preserved surface; note the external surface showing the heads of the interseminal scales and micropyles (arrowheads). Specimen T2417. Scale bars: $10 \mathrm{~mm}$ $(A), 1 \mathrm{~mm}(B)$.

1995). No microsporangiate organs are currently known that can be linked to W. carolinensis.

Interpretation. The two types of gynoecia are here interpreted as different developmental stages of $W$. carolinensis ovulate structures. The smaller specimens (fig. $7 A$ ) represent developing immature ovulate structures due to their size, spherical shape, and undifferentiated short scales that emerge from the receptacle. No micropylar tubes project beyond the gynoecia surface. One specimen is interpreted as more mature because it is larger and its shape is transitional between the spherical outline of the immature gynoecia and the ovoid, elongate shape of the mature gynoecia (fig. $7 B$ ). Moreover, it displays ongoing differentiation of the growing scales into ovules and interseminal scales, and micropyles projecting beyond the surface of the gynoecium are visible, indicating a receptive (anthetic) condition. The larger specimens (fig. 7C) represent mature ovulate structures that elongated during ovule and interseminal scale differentiation, most likely to provide space for the expanding and extending ovules and eventual mature seeds. In cross sections, long micropyles are visible that do not project beyond the gynoecium surface and are interpreted as having retracted following fertilization (Pott $2014 a$ ). The apically expanding interseminal scale heads probably formed a fleshy fruit-like structure, especially in the seed cones of early bennettitaleans (e.g., Pott et al. 2010a). This can be interpreted as the projecting micropyles having closed during seed cone maturation by the swelling interseminal scales through which the seed cones became fleshy and attractive to potential animal dispersers (Crane and Kenrick 1997; Pott et al. 2010a; Pott 2014a). The growing process is also reflected in the gradual decrease of the density (and thus increasing diameter) of the interseminal scale heads from the base of the gynoecia toward the apex (fig. 7; see also Sharma 1970, 1974; Pott 2014a).
It is interesting to note that W. carolinensis has no corona; a corona would indicate that the receptacle apically projects beyond the layer of ovulate and interseminal scales. The presence of a corona is the typical condition in most Jurassic Williamsoniaceae (Harris 1969; Pott 2014a), but it is less common if not entirely absent in Triassic and Cretaceous representatives (Watson and Sincock 1992; Pott et al. 2010a, 2014; Pott 2014a). The absence of any bracts is also an unusual feature of W. carolinensis among the Williamsoniaceae. To date, all known receptive or maturing ovulate structures are surrounded by one or several whorls of subtending sterile bracts or scale leaves (e.g., Harris 1969; Sharma 1970, 1974;

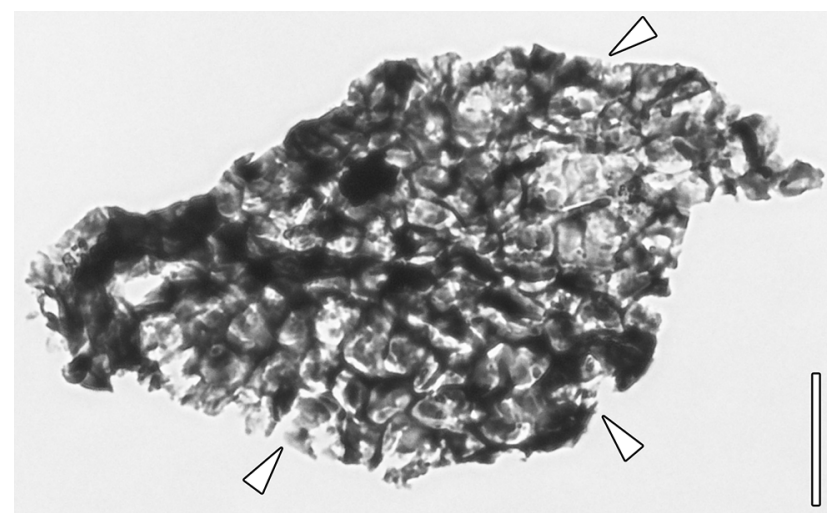

Fig. 6 Cuticle portion of an interseminal scale head from a gynoecium of Williamsonia carolinensis from the Clay pit of the Boren Clay Products Company, Chatham County, North Carolina. Arrowheads indicate present but poorly preserved stomata. Specimen T21519, extracted from specimen T2151. Scale bar: $100 \mu \mathrm{m}$. A color version of this figure is available online. 
A
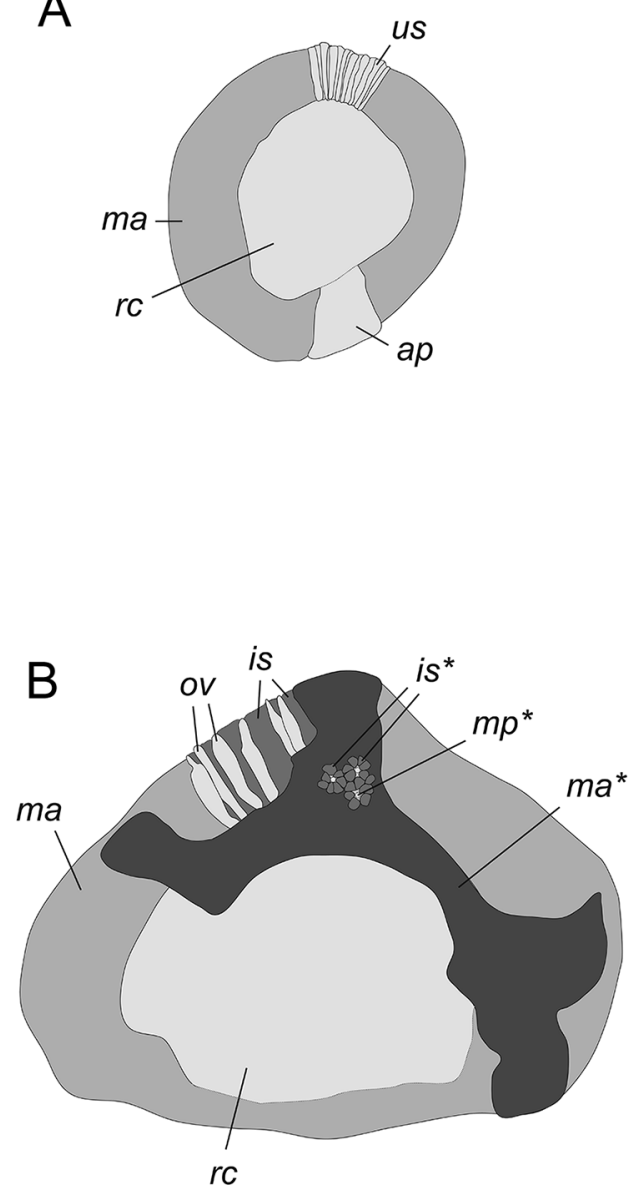

C

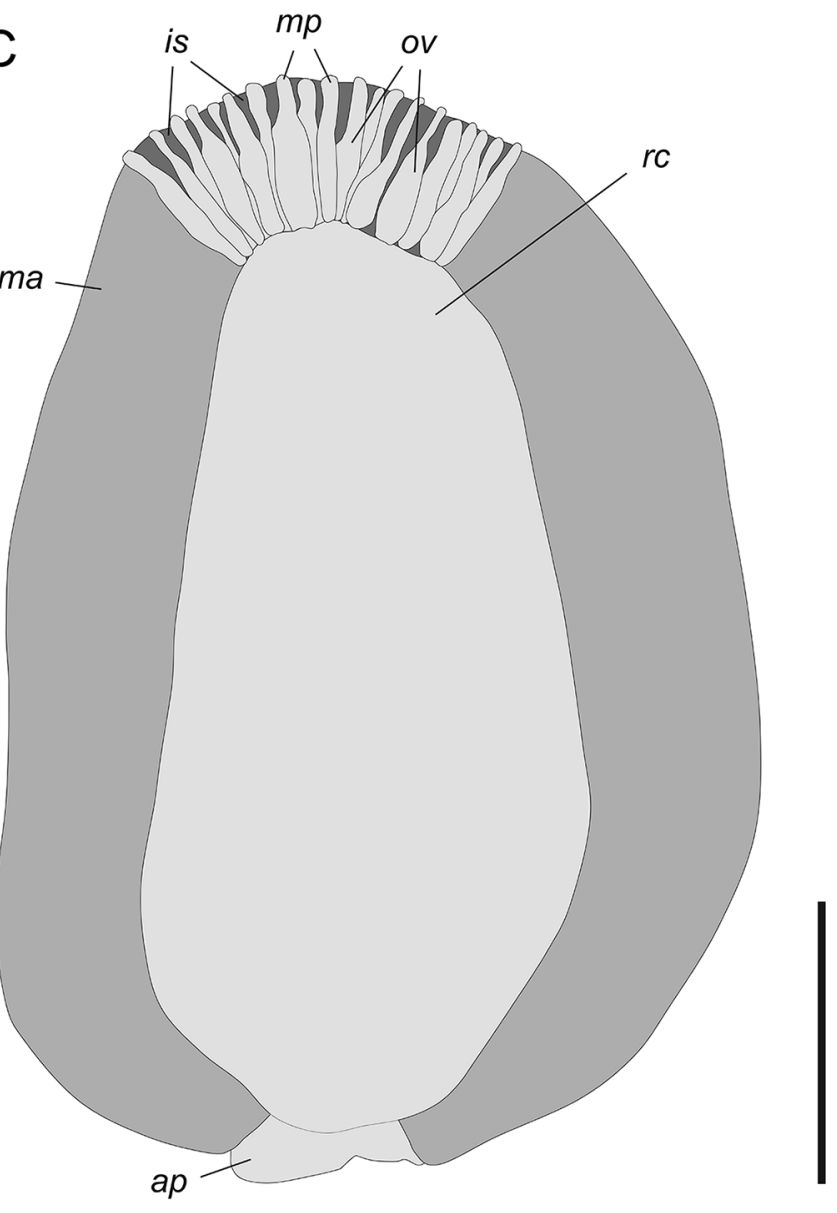

Fig. 7 Interpretative drawing of cross sections of the different developmental stages of gynoecia of Williamsonia carolinensis from the Clay pit of the Boren Clay Products Company, Chatham County, North Carolina. A, Gynoecium interpreted immature. Based on specimen T2151. $B$, Gynoecium interpreted intermediate between stage $A$ and stage $C$. Based on specimen T2417; partly visible in surface view. $C$, Gynoecium interpreted mature. Based on specimen T2155. See text for details. Abbreviations: ap, attachment point; is, interseminal scale; ma, mantle of ovules and interseminal scales; mp, micropyles; ov, ovules; rc, receptacle; us, undifferentiated scales. Asterisk indicates surface view. Scale bar: 10 mm.

Watson and Sincock 1992; Pott et al. 2010a, 2014; Popa 2014; Pott 2014a) that probably had protective functionbut in some species appeared to have a pollinator attraction function as well-leading to the interpretation that bennettitalean "flowers" converged on some of the architectural adaptations of modern flowering plants. In mature seed cones, the situation is different: bracts might have been shed during maturation processes prior to fossilization (Pedersen et al. 1989; Stockey and Rothwell 2003; Pott et al. 2010a; Pott 2014a). In W. carolinensis, the immature forms also lack bracts and, therefore, apparently never had them. How it matured without such protection or attracted pollinators is unknown.

\section{Comparison with Other Species}

From the Upper Triassic of North America (outside of Greenland), the record of bennettitaleans (Williamsoniaceae) is rather scarce (Newberry 1876; Ash 1968, 1975, 1976, 1989; Delevoryas and Hope 1976; Axsmith et al. 1995;
Weber and Zamudio-Varela 1995; Weber 1996, 2008); however, later in the Mesozoic, bennettitaleans attributed to the Cycadeoidaceae constitute a significant portion of the flora (e.g., Wieland 1906, 1916; Delevoryas 1968). Records of reproductive structures of Williamsoniaceae from this region are particularly sparse (Ash 1968; Weber 2008). Williamsonia nizhonia Ash from the Chinle Formation in Arizona is the only williamsoniaceous ovulate cone reported from the Triassic of North America north of Mexico (Ash 1968; see Stockey and Rothwell 2003 for the Cretaceous Williamsonia bockii Stockey and Rothwell). The ovulate cone of W. nizhonia is very small, the gynoecium not exceeding $1 \mathrm{~cm}$ in diameter, and the structure is surrounded by one layer of densely arranged lanceolate bracts. Also the heads of the interseminal scales yield a different type of cuticle, with the central epidermal cells characterized by papillae (Ash 1968; see Pott 2014a). Therefore, W. nizhonia is not conspecific with W. carolinensis but may be related to it. From the Upper Triassic Santa Clara Formation of Sonora, Mexico, three Williamsonia species have been described (i.e., Williamsonia 
newberryi Weber, Williamsonia sp. A, and the questionable Williamsonia opilionoides Weber), which all are different from $W$. carolinensis in having slender bracts; no information on the gynoecia is given (Weber 2008), but the figured fossils indicate that the gynoecia have a maximum diameter of about $1 \mathrm{~cm}$ (similar to W. nizhonia). Weber (2008) has identified several supposed microsporangiate bennettitalean structures from the same location (i.e., Haitingeria, Dictyotrichia Weber, Bennettistemon); however, the bennettitalean affinity of the latter two remains uncertain.

The absence of bracts in W. carolinensis could be a preservational artifact. From the Middle Jurassic of Hasty Bank in Yorkshire, United Kingdom, for example, Williamsonia hildae Harris cones apparently without bracts are known, but from there, at least one bud surrounded by Cycadolepis bracts is known (Harris 1969). However, for W. carolinensis, this is doubtful as bracts are ubiquitous in other North American species and yet missing on W. carolinensis despite the presence of specimens representing several developmental stages. Also the morphological preservation of W. carolinensis is otherwise good, as is the case for many taxa of the Pekin flora. Based on these observations, we interpret the absence of bracts in $W$. carolinensis as a real feature and suggest that it represents a derived state with biological or ecological relevance rather than an ancestral condition. The latter possibility, however, cannot be completely ruled out, as CarnianRhaetian williamsoniaceous ovulate cones usually have one whorl of bracts and Jurassic species usually produce two or more (e.g., Harris 1932, 1969; Pott et al. 2010a; Pott 2014a; Pott and McLoughlin 2014). However, most known Cretaceous Williamsoniaceae again have only one whorl of bracts, indicating a complex history for this trait (e.g., Watson and Sincock 1992; Pott et al. 2014). This issue of character polarity can ultimately be settled only with a rigorous phylogenetic analysis, which we suggest is not feasible until we know much more about the family.

Material from the Rhaetian of East Greenland (Jameson Land) assigned to different species of Bennetticarpus (Harris 1932 ) is rather fragmentary, and a comparison with W. carolinensis is difficult. According to the size ranges given by Harris (1932), the species fall in the lower range of W. carolinenis, but some of them were interpreted as fruits by Harris (1932) and thus are much smaller already when matured. Bracts have not been described for any of them, but they might have been shed during maturation. More interesting is a comparison with Wielandiella angustifolia (Nathorst) Nathorst (Pott 2014a), but even here, well-developed reproductive organs are much smaller, and the assumed seed cone (viz., Vardekloeftia sulcata Harris) is also much smaller in size than the anthetic reproductive organs of W. carolinensis (Harris 1932; Pott 2014a). This is confirming the trend of a size reduction in williamsoniaceous bennettitaleans through time as hypothesized by Pott et al. $(2010 a)$. On the other hand, Carnian-Rhaetian East Greenland was located much farther north $\left(\mathrm{ca} .30^{\circ} \mathrm{N}\right)$ than the equatorial Deep River Basin, and the size differences of reproductive organs and foliage might have been due to shorter growing seasons in higherlatitude regions (Werner's rules of botanical geography) compared to the tropical regions along the (paleo)equator, where large-leaved plants prevail.

\section{Associated Sterile Foliage of W. carolinensis}

The two largest W. carolinensis specimens, interpreted here as mature, occur on the same slab nested among abundant, overlapping sterile foliage specimens of Eoginkgoites sidneyi (Axsmith et al. 1995). Some authors argue that such cooccurrence on the same slabs is indicative of conspecificity (e.g., Harris 1969), but this is proven only if fossils are found in clear organic connection or cuticles strongly indicate conspecificity (e.g., Pott and Kerp 2008; Pott et al. 2010a; Popa 2014; Pott 2014a; Pott and McLoughlin 2014). However, at least two other foliage types occur at the Boren locality that cannot be entirely ruled out as having affinity with W. carolinensis. Laurozamites paraiconicus Weber and Zamudio-Varela is a common foliage type, and its bennettitalean affinity is secure based on cuticles obtained from specimens attached to stems of Ischnophyton Delevoryas and Hope (Delevoryas and Hope 1976; Weber and Zamudio-Varela 1995). Gensel (1986) reported the presence of Pterophyllum Brongniart and figured a specimen, but no cuticles have been described. In any case, neither of these other foliage types is closely associated with the W. carolinensis specimens. Furthermore, Eoginkgoites is relatively rare at the Boren locality, and we submit that an accidental association with this leaf type would be unlikely if W. carolinensis actually belonged with one of the other foliage types. The evidence presented above indicating that the assemblage was not transported far supports the suggested conspecificity of the bennettitalean reproductive structures described here. It also indicates that the association of these reproductive structures and the intact Eoginkgoites leaves described below cannot be easily dismissed as a preservational artifact. Despite this intriguing association, we refrain from asserting definitive conspecificity in the absence of attachment or cuticular evidence.

If $W$. carolinensis is the reproductive unit of a plant bearing E. sidneyi foliage, which we submit is likely based on the evidence presented above, a third type of bennettitalean foliage can be added to the diversity of forms among williamsoniaceous plants. To the well-known entire-margined foliage (i.e., Nilssoniopteris Nathorst; Pott et al. 2007; Pott and McLoughlin 2009) and once- or twice-pinnate foliage (e.g., Pterophyllum, Zamites Brongniart, Anomozamites Schimper, Ptilophyllum Morris in Grant, and Otozamites Braun in Münster; cf. Harris 1969; Ash 1976, 2001; Schweitzer and Kirchner 2003; McLoughlin and Pott 2009; Pott and McLoughlin 2009) may be added the unusual fan-shaped, almost palmate but still pinnate leaves of the Eoginkgoites form (Axsmith et al. 1995).

The presence and distribution of sterile bennettitalean foliage in the Upper Triassic in North American deposits are similarly restricted as are the fertile elements. Besides the already mentioned Eoginkgoites leaves, foliage attributable to Zamites (or Otozamites) and Nilssoniopteris has been described from the Chinle Formation of the Fort Wingate area (Ash 1968, 1975, 1989) and the Pekin Formation (Delevoryas and Hope 1976). From the Upper Triassic of Sonora, Mexico (Santa Clara Formation), foliage of Pterophyllum, Otozamites, Zamites, Anomozamites, Macropterygium Schimper, and Nilssoniopteris has been mentioned (Newberry 1876; Weber 1996, 2008); Weber and Zamudio-Varela (1995) in- 
troduced Laurozamites for the North American pinnate foliage from Chinle, Newark, and Sonora and assigned all foliage earlier attributed to Pterophyllum, Otozamites, and Zamites to it, as Laurozamites should "represent a more natural taxon restricted to North America, at least during the Late Triassic." Foliage assigned to any supposedly bennettitalean genera by Fontaine (1883) and Bock (1969) from Upper Triassic strata of North America has been discussed and included in the studies carried out by the scholars mentioned in this paragraph. The assignments made by Fontaine (1883) and Bock (1969) have largely been questioned and subsequently corrected.

\section{The Position of Eoginkgoites among Bennettitales}

Bennettitalean foliage types can roughly be divided into two groups, viz., entire-margined foliage (Nilssoniopteris) and once pinnate forms with multiple leaflets such as Pterophyllum, Zamites, etc. (see Watson and Sincock 1992; Pott and McLoughlin 2009). Some forms display intermediate or transitional leaves such as the incompletely segmented Nilssoniopteris haidingeri Stur ex Krasser (Pott et al. 2007) or Anomozamites foliage (Pott and McLoughin 2009; Pott 2014a). Eoginkgoites, in contrast, comprises once pinnate foliage with only a few (up to 5) leaflet pairs and a very long "naked" petiole. The appearance of the leaves is more similar to a fanshaped Ginkgo leaf; however, the leaves are still pinnate, with the reduced number of leaflets confined to the apical portion of the rachis, giving the leaf a palmate appearance. This leaf type is so far unique among Bennettitales. Eoginkgoites is restricted to the Upper Triassic of North America (e.g., Ash 1976). Ash (1976) argues that Eoginkgoites was probably derived from a typical pinnate leaf by the reduction of the number of leaflets and telescoping of the rachis, which would make it a derived form. The occurrence of such a leaf type so early in the evolutionary history of the Bennettitales is remarkable.

\section{Conclusions}

The origin of Bennettitales is still obscure, but records like that reported here support the view that the rise of the Williamsoniaceae, which are considered to be the older family of the Bennettitales (Alvin et al. 1967; Pott 2014a), must have taken place much earlier than the Carnian-Norian, followed by a rapid diversification-especially with regard to leaf morphology. Williamsoniaceous bennettitaleans were wellestablished members of Carnian floras all over the world (e.g., North America, Svalbard, central Europe, South Africa, Australia), underscoring the likelihood of a much earlier provenance of the group (Pott 2014b). However, Bennettitales older than the Ladinian-Carnian have yet to be unambiguously identified (Pott et al. 2010b). This fact-along with the presence of diverse leaf morphologies and reproductive structures in the Carnian-suggests that even if the Bennettitales are older, their morphological divergence and rise to geographical and ecological importance during the Late Triassic were very rapid.

\section{Acknowledgments}

C. Pott thanks Thomas Denk, Department of Palaeobiology, Swedish Museum of Natural History, Stockholm, for help with the SEM and acknowledges funding from the Swedish Research Council (Vetenskapsrådet), Stockholm. B. J. Axsmith thanks Edith Taylor, Thomas N. Taylor, and Rudolph Serbet of the University of Kansas, Lawrence, for facilitating continued access to the Pekin Formation plant collection. B. J. Axsmith also thanks Andrew Heckert of Appalachian State University, Boone, North Carolina, for providing a copy of his map of the NC Triassic. Johanna H. A. van Konijnenburgvan Citterat, Utrecht and Leiden, The Netherlands, and Mihai E. Popa, Bucharest, Romania, are thanked for reviewing the article.

\section{Literature Cited}

Alvin KL, PDW Barnard, TM Harris, NF Hughes, RH Wagner, A Wesley 1967 Gymnospermophyta. Pages 247-267 in WB Harland, CH Holland, MR House, NF Hughes, AB Reynolds, MJS Rudwick, GE Satterthwaite, LBH Tarlo, EC Willey, eds. The fossil record. Geological Society of London, London.

Ash SR 1968 A new species of Williamsonia from the Upper Triassic Chinle Formation of New Mexico. J Linn Soc Bot 61:113-120.

1975 Zamites powelli and its distribution in the Upper Triassic of North America. Palaeontogr Abt B 149:139-152.

1976 The systematic position of Eogingkoites. Am J Bot 63:1327-1331.

1989 The Upper Triassic Chinle flora of the Zuni Mountains, New Mexico. New Mexico Geological Society Fieldbook, 40th Field Conference, Southeastern Colorado Plateau. New Mexico Geological Society, Socorro, NM.

2001 New cycadophytes from the Upper Triassic Chinle Formation of the southwestern United States. Paleobios 21:15-28.

Ash SR, RJ Litwin 1996 Two new species of the pinnate microsporophyll Pramelreuthia from the Upper Triassic of the southwestern United States. Am J Bot 83:1091-1099.

Axsmith BJ, M Krings, TN Taylor 2001 A filmy fern from the Upper Triassic of North Carolina (USA). Am J Bot 88:1558-1567.
Axsmith BJ, TN Taylor, T Delevoryas, RC Hope 1995 A new species of Eoginkgoites from the Upper Triassic of North Carolina, USA. Rev Palaeobot Palynol 85:189-198.

Bock W 1969 The American Triassic flora and global distribution. Geological Center, North Wales, PA.

Carruthers W 1870 (1868) On fossil cycadean stems from the secondary rocks of Britain. Trans Linn Soc Lond 26:675-708.

Crane PR, PS Herendeen 2009 Bennettitales from the Grisethorpe Bed (Middle Jurassic) at Cayton Bay, Yorkshire, UK. Am J Bot 96: 284-295.

Crane PR, P Kenrick 1997 Diverted development of reproductive organs: a source of morphological innovation in land plants. Plant Syst Evol 206:161-174.

Delevoryas T 1968 Investigations of North American cycadeoids: structure, ontogeny and phylogenetic considerations of cones of Cycadeoidea. Palaeontogr Abt B 121:122-133.

Delevoryas T, RC Hope 1976 More evidence for a slender growth habit in Mesozoic cycadophytes. Rev Palaeobot Palynol 2:93-100.

Engler A 1892 Syllabus der Vorlesungen über specielle und medicinischpharmaceutische Botanik. Borntraeger, Berlin.

Fontaine WM 1883 Contributions to the knowledge of the older Mesozoic flora of Virginia. Government Printing Office, Washington, DC. 
Gensel P 1986 Plant fossils of the Upper Triassic Deep River basin. Pages 82-86 in PJW Gore, ed. Depositional framework of a Triassic rift basin: the Durham and Sanford sub-basins of the Deep River basin, North Carolina. Society of Economic Paleontologists and Mineralogists, Tulsa, OK.

Harris TM 1932 The fossil flora of Scoresby Sound, East Greenland. 3. Caytoniales and Bennettitales. Medd Gronl 85:1-133.

1969 The Yorkshire Jurassic flora: Bennettitales. Vol 3. Trustees of the British Museum, London.

Hope RC, OC Patterson III 1969 Triassic flora of the Deep River basin, North Carolina. N C Dep Conserv Dev Div Miner Resour Spec Publ 2:1-12.

Hsü J 1948 On some fragments of bennettitalean "flowers" from the Liling coal series of East Hunan. Nat Peking Univ Fifteenth Anniv Pap Geol Ser 1948:57-68.

Krasser F 1917 Studien über die fertile Region der Cycadophyten aus den Lunzer-Schichten: Mikrosporophylle und männliche Zapfen. Denkschr Akad Wiss Math-Naturwiss Kl 94:489-553.

1919 Studien über die fertile Region der Cycadophyten aus den Lunzer Schichten: Makrosporophylle. Denkschr Akad Wiss Math-Naturwiss K1 97:1-32.

Kräusel R, F Schaarschmidt 1966 Die Keuperflora von Neuewelt bei Basel. IV. Pterophyllen und Taeniopteriden. Schweiz Palaeontol Abh 84:3-44.

McLoughlin S, C Pott 2009 The Jurassic flora of Western Australia. J Geol Soc Swed 131:113-136.

McNeill J, FR Barrie, WR Buck, V Demoulin, W Greuter, DL Hawksworth, PS Herendeen, et al 2012 International Code of Nomenclature for algae, fungi, and plants (Melbourne Code) adopted by the Eighteenth International Botanical Congress Melbourne, Australia, July 2011. Koeltz Scientific, Konigstein.

Nathorst AG 1909 Paläobotanische Mitteilungen. 8. Über Williamsonia, Wielandia, Cycadocephalus und Weltrichia. K Sven Vetenskapsakad Handl 45:3-37.

Newberry J 1876 Geological report. Pages 9-118 in JN Macomb, ed. Report of the exploring expedition from Santa Fé, New Mexico, to the junction of the Grand and Green Rivers of the great Colorado of the West. US Army Engineering Department, Washington, DC.

Pedersen KR, PR Crane, EM Friis 1989 The morphology and phylogenetic significance of Vardekloeftia Harris (Bennettitales). Rev Palaeobot Palynol 60:7-24.

Popa ME 2014 Early Jurassic bennettitalean reproductive structures of Romania. Palaeobiol Palaeoenviron 94:327-362.

Pott C 2014a A revision of Wielandiella angustifolia-a shrub-sized bennettite from the Rhaetian-Hettangian of Scania, Sweden, and Jameson Land, Greenland. Int J Plant Sci 175:467-499.

$2014 b$ The Triassic flora of Svalbard. Acta Palaeontol Pol 59:709-740.

Pott C, M Guhl, J Lehmann 2014 The Early Cretaceous flora from the Wealden facies at Duingen, Germany. Rev Palaeobot Palynol 201:75-105.
Pott C, H Kerp 2008 Mikroskopische Untersuchungsmethoden an fossilen Pflanzenabdrücken. Praparator 54:50-61.

Pott C, M Krings, H Kerp 2007 The first record of Nilssoniopteris (Gymnospermophyta, Bennettitales) from the Carnian (Upper Triassic) of Lunz, Lower Austria. Palaeontology 50:1299-1318.

Pott C, M Krings, H Kerp, EM Friis 2010a Reconstruction of a bennettitalean flower from the Carnian (Upper Triassic) of Lunz, Lower Austria. Rev Palaeobot Palynol 159:94-111.

Pott C, S McLoughlin 2009 Bennettitalean foliage in the RhaetianBajocian (latest Triassic-Middle Jurassic) floras of Scania, southern Sweden. Rev Palaeobot Palynol 158:117-166.

— 2014 Divaricate growth habit in Williamsoniaceae: unravelling the ecology of a key Mesozoic plant group. Palaeobiol Palaeoenviron 94:307-326.

Pott C, S McLoughlin, A Lindström $2010 b$ Late Palaeozoic foliage from China displays affinities to Cycadales rather than to Bennettitales necessitating a re-evaluation of the Palaeozoic Pterophyllum species. Acta Palaeontol Pol 55:157-168.

Schweitzer H-J, M Kirchner 2003 Die rhäto-jurassischen Floren des Iran und Afghanistans. 13. Cycadophyta. III. Bennettitales. Palaeontogr Abt B 264:1-166.

Sharma BD 1970 On the structure of the seeds of Williamsonia collected from the Middle Jurassic rocks of Amarjola in the Rajmahal Hills, India. Am J Bot 34:1071-1078.

1974 Ovule ontogeny in Williamsonia Carr. Palaeontogr Abt B 148:137-143.

Stockey RA, GW Rothwell 2003 Anatomically preserved Williamsonia (Williamsoniaceae): evidence for bennettitalean reproduction in the Late Cretaceous of western North America. Int J Plant Sci 164:251-262.

Watson J, CA Sincock 1992 Bennettitales of the English Wealden. Monogr Palaeontogr Soc 588:1-228.

Weber R 1996 Review of Macropterygium Schimper ("Cycadophyta," presumed Bennettitales) and a new species from the Upper Triassic of Sonora, Mexico. Rev Mex Cienc Geol 13:201-220.

2008 Dictyorichia gen. nov., Haitingeria Krasser, y otros órganos reproductivos o apendiculares de cicadofitas, Triásico Tardío, Sonora, México. Bol Inst Geol Univ Nac Auton Mex 115:117-149.

Weber R, G Zamudio-Varela 1995 Laurozamites, a new genus and new species of bennettitalean leaves from the Late Triassic of North America. Rev Mex Cienc Geol 12:68-93.

Whiteside JH, DS Grogan, PE Olsen, DV Kent 2011 Climatically driven biogeographic provinces of Late Triassic tropical Pangea. Proc Natl Acad Sci 108:8972-8977.

Wieland GR 1906 American fossil cycads: structure. Vol 1. Carnegie Institution, Washington, DC.

1916 American fossil cycads: taxonomy. Vol 2. Carnegie Institution, Washington, DC.

Zavialova N, JHA Van Konijnenburg-van Cittert, M Zavada 2009 The pollen ultrastructure of Williamsoniella coronata Thomas (Bennettitales) from the Bajocian of Yorkshire. Int J Plant Sci 170:11951200. 